\title{
Will the Proposed Application of Basel II in the United States Encourage Increased Bank Merger Activity? Evidence from Past Merger Activity
}

February 18, 2004

Timothy H. Hannan

Steven J. Pilloff

\footnotetext{
*Board of Governors of the Federal Reserve System. The views expressed are those of the authors and do not necessarily represent those of the Board of Governors of the Federal Reserve System or its staff. The authors would like to thank Robert Avery, Allen Berger, Nora Barger, Ed Ettin, Jim Follain, Diana Hancock, Erik Heitfield, Beverly Hirtle, Myron Kwast, Robin Prager and staff of the FDIC, OCC, and OTS for comments and suggestions, Shaista Ahmed, David Kite, and Onka Tenkean for excellent research assistance, and Cecilia Tripp for valuable secretarial help.
} 


\section{Introduction}

One of the most important elements of the proposed Basel II capital accord is the advanced internal ratings-based (A-IRB) approach to regulatory capital requirements. The A-IRB approach differs substantially from the Basel I approach and the proposed standardized approach in Basel II in that a banking organization's internal assessments of key risk considerations serve as primary inputs in the calculation of capital requirements. Because the A-IRB approach is based on banks' internal assessments using systems validated by supervisors, it offers the benefit of more risk-sensitive minimum regulatory capital requirements. Those banking organizations using the A-IRB approach will be required to employ sophisticated risk-measurement techniques that involve a statistical and quantitative assessment of risk.

Under the current proposal for banking organizations in the United States, organizations with total banking (and thrift) assets of at least $\$ 250$ billion or at least $\$ 10$ billion in on-balance-sheet foreign exposure-about ten large organizations based on current balance sheets-would be required to adopt A-IRB. Other banking organizations may also choose to adopt A-IRB, provided they have developed the necessary infrastructure to measure and manage risk. While any bank may "opt in" if it meets regulatory standards, only a few of the largest U.S. banking organizations initially will have in place the infrastructure required to employ such techniques, implying that the AIRB approach will be used at the outset only by a small group of the largest banking organizations. The result would be a bifurcated system in which the vast majority of 
banking organizations would be subject to the current minimum capital regulations in this country, essentially based on Basel I, while the largest banking organizations would be subject to the more risk-sensitive and flexible method of determining minimum regulatory capital requirements. It is anticipated that a number of larger banking organizations would join the initial set relatively soon after the implementation date.

While this bifurcated system may raise the regulatory capital requirements for some A-IRB banks, it is likely to result in somewhat lower minimum regulatory capital requirements, on average, for the banking organizations that can avail themselves of this approach, relative to the minimum regulatory capital requirements applied to the vast majority of banks that initially cannot. ${ }^{1}$ Concerns have been raised that this disparity would provide an undue competitive advantage to many of the largest banking organizations in the country. Furthermore, concerns have been raised that both the excess regulatory capital that would be created at A-IRB organizations as a result of reduced capital requirements and the aforementioned competitive advantage associated with those reduced requirements would fuel their acquisitions of non-adopting banking organizations. Such concerns have not been the subject of empirical examination. In this paper, we bring data to bear on the second of these concerns: that BHCs that adopt A-IRB will

${ }^{1}$ See the Third Quantitative Impact Study, which was conducted by the Basel Committee on Banking Supervision to understand the possible effects that the Basel II proposals (as of late 2002) might have on capital levels across participating banks. The document can be found at www.bis.org/bcbs/qis/qis3.htm. Another quantitative impact study is planned for the second half of 2004. 
aggressively acquire other banking organizations. ${ }^{2}$

There are two primary consequences of the A-IRB approach to capital requirements that suggest to some observers that A-IRB BHCs would increase acquisition activity. Arguments based on these consequences may be usefully designated as "excess regulatory capital" and "relative capital advantage" arguments.

"Excess regulatory capital" arguments assert that merger activity would increase as a result of the excess regulatory capital that would be created by the lower capital requirements stemming from adoption of A-IRB. Excess regulatory capital could fuel acquisitions for a number of different reasons. For example, a BHC desiring to engage in a certain acquisition may be deterred under current capital requirements, because the merger might cause the combined entity to violate existing capital standards. However, a reduction in regulatory requirements and a consequent increase in excess regulatory capital might encourage the acquisition by significantly reducing the likelihood of the combined BHC failing to meet the new, more lenient capital standards.

Another example of an "excess regulatory capital" argument is that, with an increase in excess regulatory capital, BHCs could increase their return on equity (ROE) by increasing the amount of earning assets against which a given amount of capital is held (or reducing capital held against a given amount of earning assets). Increased ROE may in turn raise $\mathrm{BHC}$ valuation, which could facilitate an increase in acquisition activity.

\footnotetext{
${ }^{2}$ Several other studies that look at the competitive effect of A-IRB on specific products are being conducted by Federal Reserve economists.
} 
The focus of "relative capital advantage" arguments is on the difference in the capital standards applied to A-IRB BHCs and other banking organizations, maintaining that lower capital requirements for BHCs operating under A-IRB, relative to those of banking organizations operating under existing standards, would result in increased acquisition activity. Specifically, it is alleged that A-IRB BHCs would have an incentive to acquire banks not subject to A-IRB capital standards because target banks would be worth more to A-IRB BHCs than to current owners. Different valuations would exist because A-IRB BHCs are expected to face regulatory capital requirements that would be lower than those of the banking organizations that they might acquire. Consequently, they could acquire such organizations and increase the return on equity associated with the acquired assets by either increasing income-earning assets without adding capital or holding less capital against the newly acquired assets. ${ }^{3}$

Both "excess regulatory capital" and "relative capital advantage" arguments rely on the assumption that current regulatory capital requirements are "binding" in the sense that large banking organizations are restricted from doing what they would otherwise do in the absence of current minimum capital regulations. Regulatory capital requirements would

\footnotetext{
${ }^{3}$ Although other arguments for a positive relationship between A-IRB status and acquisition activity can be made, we believe that the primary reasons that acquisition activity may be affected by A-IRB depend on "excess regulatory capital" and the "relative capital advantage." An example of an alternative explanation is that the market values the improved ability to measure and manage risk associated with adopting A-IRB, thereby raising the valuation of A-IRB BHCs and enabling them to increase their acquisition activity. In addition, the costs and benefits associated with the A-IRB approach could influence decisions by banks not using the A-IRB approach to merge with each other. This study does not examine the effect of A-IRB on mergers of this type.
} 
not be binding if market-based considerations dictated higher levels of capital than those imposed by regulation, or if, as some have argued, "capital arbitrage" techniques currently employed by the larger banking organizations allow them largely to avoid, with minor costs, the constricting effects of existing minimum regulatory capital requirements. ${ }^{4}$

Ultimately, the question of whether, in the United States, adoption of the bifurcated application of Basel II would result in a substantial increase in merger activity by banking organizations using the A-IRB approach must be assessed by examining relevant data. The best approach, were it available, would be to examine the results of previous reductions in regulatory capital requirements that applied to some banking organizations but not to others, and assess whether substantial relative increases in the acquisition activity of those granted the reduction occurred as a result of the change. Unfortunately, no such reduction in capital requirements has taken place in recent decades. Therefore, we must assess the issue by pursuing less definitive, but nonetheless informative, approaches.

Specifically, we conduct two different types of tests. The first type uses recent data on merger activity and $\mathrm{BHC}$ capital ratios to determine if, all else equal, large banking organizations with greater excess regulatory capital exhibit a greater tendency to subsequently acquire other banks. Such a finding would be consistent with the argument that allowing large BHCs to operate under lower capital requirements (and thereby

${ }^{4}$ See Jones (2002) for a detailed discussion. 
increase excess regulatory capital) would result in expanded acquisition activity on their parts. This approach, however, is subject to several sources of potential endogeneity bias, only some of which are eliminated by the fixed-effects statistical procedure that we employ.

In part for this reason, we also conduct a test based on observations of what happened the last time that capital standards changed substantially for banks. It is argued that the advent of "prompt corrective action" (PCA) standards in the early 1990s increased capital requirements for banks, a change that was in the opposite direction of the reduction of regulatory minimum capital requirements that is expected to occur, on average, for BHCs that adopt the A-IRB approach. ${ }^{5}$ Taking a sample of large BHCs that did not appear to be constrained by the capital requirements in effect before the advent of PCA, and, further, would not have been constrained under the pre-PCA capital standards after the adoption of PCA, we compare the change (from the period before to the period after PCA) in merger activity exhibited by those BHCs that did and did not become capital constrained after more stringent regulatory capital standards became relevant. A finding that BHCs constrained by the advent of PCA standards reduced their merger activity by more (or increased it by less) than those not so constrained would be supportive of the hypothesis that relaxation of regulatory capital requirements (as anticipated, on average,

${ }^{5}$ Although the capital standards of "prompt corrective action" are relevant for banking institutions, not bank holding companies, the amount of capital held by bank holding companies should be affected by the "prompt corrective action" standards. 
for BHCs that adopt the A-IRB approach) would result in greater merger activity by AIRB BHCs.

Our tests are more relevant to the "excess regulatory capital" arguments for increased merger activity by A-IRB banking organizations than for "relative capital advantage" arguments. However, as discussed below, a number of studies have been conducted that are not supportive of "relative capital advantage" arguments. The results of this literature uniformly reject the hypothesis that acquirers seek to purchase more highly capitalized targets-a finding that is not consistent with the notion that acquirers prefer targets with greater potential for ROE improvement from increased leverage.

Still, the use of historical data in previous studies and in the current paper limits our ability to capture the extent to which future acquisition activity might occur as a result of the "relative capital advantage" associated with A-IRB. Further, it restricts our ability to address the possibility that acquisitions driven by different capital standards would be most likely to occur in the case of targets holding assets that require much less capital under A-IRB. However, several forthcoming studies by Federal Reserve economists will assess whether A-IRB status would be likely to provide adopters with a substantial competitive advantage in the provision of loans to small and medium size enterprises, loans for residential mortgages, and credit card loans. The results of these studies will be important in assessing how acquisition activity could change as a result of the "relative capital advantage" associated with A-IRB.

The plan of the paper is as follows. Section II discusses the literature relevant to 
the relationship between bank merger activity and capitalization. Section III describes the proposed empirical tests, section IV describes the samples, data, and variables, and section V presents empirical results. A final section summarizes and concludes. To preview results, we do not find convincing evidence that past levels of excess regulatory capital or past changes in capital requirements have had a substantial effect on merger activity. Results of the two tests suggest relationships that are in the direction consistent with the concern that a reduction in minimum capital requirements for large banking organizations that adopt A-IRB would result in increased merger activity on their part, but, with a few exceptions, results are not statistically significant. When results are statistically significant, relevant magnitudes are found to be quite small.

\section{Relevant Literature}

A very large literature has addressed the question of why banking organizations acquire other banking institutions. ${ }^{6}$ Several reasons that banks merge have emerged from this literature, and these same reasons are also commonly cited by bankers and other industry analysts. Specifically, the prospects for increased efficiency and potential gains from diversification are noted as the key drivers of acquisition activity. Moreover, of particular importance to the U.S. banking industry, relaxation of longstanding interstate banking restrictions is widely believed to have sparked extensive consolidation of an

${ }^{6}$ For comprehensive reviews, see Berger, Demsetz, and Strahan (1999) and Group of Ten (2001), available at www.bis.org. 
industry that was decentralized for over one hundred years. Interestingly, capital is rarely cited as an important issue in the question of why banks merge. Indeed, few studies have sought to investigate the role of capital, especially that of the acquirer's capitalization relative to regulatory requirements. The scarcity of such studies likely reflects the belief that such considerations play a minor role at best in explaining mergers in the banking industry.

The only study that we know of to investigate the acquiring institution's capitalization as a determinant of merger activity was conducted by O'Keefe (1996), who found that acquirers in the large sample of banks that he investigated had significantly lower equity capitalization rates than their nonacquiring peers. Because it suggests that better capitalized banks are less likely to acquire other banks, this finding does not support "excess regulatory capital" arguments that banking organizations, holding increased excess regulatory capital as a result of reductions in minimum regulatory capital requirements, would increase the rate at which they acquire other banking organizations. O'Keefe's sample, however, is not restricted to the very large bank holding companies of concern in this study, so this finding may have limited relevance to the behavior of the BHCs that adopt A-IRB.

Several studies report evidence relevant to "relative capital advantage" arguments, which our empirical tests do not address very directly. These arguments, as noted above, assert that, with lower capital requirements than those of their potential targets, A-IRB BHCs would have an incentive to acquire these better capitalized targets and increase the 
return on equity associated with target assets by reducing the capital held against those assets. An implication of this argument for past merger behavior is that acquirers should have found more highly capitalized banks relatively more attractive as acquisition targets.

A fairly large number of studies report results that contradict this implication. We know of at least five studies-Hannan and Rhoades (1987), Amel and Rhoades (1989), O'Keefe (1996), Moore (1997), and Wheelock and Wilson (2000)-that sought to determine the characteristics of banking organizations that make them more likely to be a target in a future bank acquisition and that also included the bank's capitalization as a potential determinant. Using various time periods and various samples, all of these studies find that more highly capitalized banks are less likely, not more likely, to be acquired, all else equal. Although the reason for this uniform finding is ambiguous, the finding is clearly not consistent with the "relative capital advantage" argument.

Another study, by Houston, James, and Ryngaert (2001), addresses in a different way the role of capital as a motivation for bank mergers. As a part of their study, the authors obtained from both managers and analysts opinions and, in some cases, estimates of the sources of expected merger-related gains. Of the 41 mergers on which such information could be obtained, capital structure benefits were noted in only five cases. In four of these cases, analysts noted that the merger might enable the combined bank to free up excess capital, a benefit that would be consistent with "relative capital advantage" arguments. However, because capital is cited in such a small share of the acquisitions in their analysis, their findings seem to suggest that capital has not played a major role in 
explaining why banks make acquisitions.

\section{Empirical Tests}

Test 1. Our first test requires estimation of the relationship between BHC capitalization and subsequent BHC merger activity, using data obtained for recent years. The rationale for this test rests on the presumption that some banking organizations in the recent past have, for whatever reason, found themselves in the position of having capital in excess of the level that they would hold because of regulatory capital requirements, while other banking organizations have found themselves with no such excess and thus may have been constrained by regulatory capital requirements.

The level of capital that BHCs feel bound to maintain because of regulatory requirements may include some additional "cushion" above the required regulatory minimums. Such cushions may be maintained for protection against poor performance or other unanticipated events, and the size of this cushion may differ from one BHC to another, depending on the BHC's risk and other factors. ${ }^{7}$

With this in mind, we seek in this test to determine if BHCs that find themselves with excess regulatory capital exhibit a greater subsequent tendency to acquire other banking organizations than do BHCs that are more constrained by regulatory

${ }^{7}$ There is ample evidence that most BHCs chose to maintain some kind of cushion or buffer above minimum regulatory requirements and that its size depends on portfolio characteristics and other factors. See, for example, Hancock and Wilcox (2002). 
requirements. The finding of a positive relationship between observed capital ratios and merger activity or the finding of a discreet increase in merger activity at some level of capitalization representing a plausible critical level, would be consistent with the predictions of "excess regulatory capital" arguments that relaxation of capital constraints leads to more merger activity. ${ }^{8}$

A point that bears emphasizing, however, is that if the level of capitalization required by the market were greater than that dictated by regulation, or, equivalently, if capital arbitrage allowed BHCs to circumvent regulatory capital requirements with little cost, then there would be little reason to expect a relationship between excess regulatory capital and merger activity.

We can test for this hypothesized relationship by estimating the following relationships:

$$
\begin{aligned}
& M^{i}=\beta_{0}+\beta_{1}(K / A)^{i+} \beta_{2} X+\varepsilon_{i}, \text { and } \\
& M^{i}=\alpha_{0}+\alpha_{1} K A 1+\alpha_{2} K A 2+. .+\alpha_{\mathrm{n}} K A \mathrm{n}+\alpha_{\mathrm{n}+1} X+\mu_{i},
\end{aligned}
$$

where $M^{i}$ denotes the level of merger activity of $\mathrm{BHC}_{\mathrm{i}},(K / A)^{i}$ denotes its capital asset ratio, and $K A 1, K A 2, \ldots K A \mathrm{n}$ denote binary variables that receive values of 1 if $(K / A)^{i}$ is in a

${ }^{8}$ An increase in capital could lead to less, rather than more, merger activity if BHCs with low capital ratios engage in greater acquisition activity than better capitalized BHCs. This could occur because weakly capitalized organizations may purchase highly capitalized targets to increase the capitalization of the combined entity, relative to the pre-merger acquirer. If raising capital levels is a motivation for some mergers, then test results will reflect these mergers, which could obscure the effect of acquisition activity that was conducted for reasons consistent with "excess regulatory capital" arguments. To the extent that such differing types of mergers take place, we believe that results that reflect the average mix of these different types of mergers are the most relevant for understanding the potential effects of A-IRB. 
defined range of values and zero otherwise. Equation (1) imposes a linear relationship between $M^{i}$ and $(K / A)^{i}$, while equation (2) allows the relationship to vary across different ranges of $(K / A)^{i}$ but not to vary within those ranges. The vector $X$ denotes other explanatory variables that may influence observed merger activity, and $\varepsilon_{i}$ and $u_{i}$ denote error terms. Finding that $\beta_{1}>0$ in estimations of (1) would be consistent with the hypothesis that merger activity increases with capitalization (and equivalently, excess regulatory capital), and finding that coefficients on $K A 1, K A 2, \ldots, K A \mathrm{n}$ are positive and increasing in magnitude as capitalization increases would also be consistent with the hypothesis.

If, as noted above, different BHCs set different cushions above the regulatory minimum, estimates of (2) could not be used to identify some critical level of capital below which BHCs are constrained. Under these circumstances, a given binary variable might correctly classify one $\mathrm{BHC}$ as not being bound by regulatory requirements, while incorrectly classifying another BHC that was, because of a higher cushion, in fact constrained by such requirements.

Biased estimates attributable to various forms of endogeneity are an important concern in assessing the results of estimations of (1) and (2). Any unobservable characteristic of BHCs that influences both the propensity of a BHC to acquire other banking organizations and its capitalization would impart a bias to the relevant coefficients. To reduce, but unfortunately not eliminate, this possibility, explanatory variables are calculated either for the year prior to that for which merger activity is 
measured, or, in the case of balance sheet variables, at the beginning of the year for which merger activity is measured. More importantly, (1) and (2) are estimated using panel datasets consisting of annual observations of large BHCs over two time periods: The first, from 1998 to 2002, is designed to obtain the benefits of panel data estimation using only the most recent (and relevant) five years of available data. A second and longer period, from 1993 to 2002, is also used, since it allows for more annual observations of merger activity and capitalization.

Reported estimations incorporate both year and BHC fixed effects. This approach, in essence, controls for all BHC-specific characteristics that do not vary over time and for all time-specific characteristics that do not vary across BHCs. The inclusion of BHC fixed effects in particular eliminates potential sources of spurious correlation that might arise in comparing one $\mathrm{BHC}$ with another.

Spurious correlations in the form of endogeneity bias may result, however, if a time varying unobserved variable influences both a BHC's merger activity and its level of capital (or excess capital) over time in a way different from its effect on other BHCs in the sample. This type of correlation would exist, for example, if BHCs intent on making acquisitions first increase capital levels. The existence of such a correlation between merger activity and measures of capital would bias upward estimates of the coefficients on measures of capital (or excess regulatory capital), resulting in estimates that would overstate the actual expected change in merger activity that would accompany a change in 
capital requirements. $^{9}$

Test 2. The second test that we conduct should not be as vulnerable to endogeneity bias but requires that we go back considerably in time to assess the impact on merger activity of a previous change in capital requirements. Specifically, we look at the effect on merger activity attributable to the adoption of more restrictive capital standards. Passed into law in December 1991 and fully implemented at the end of 1992, the "prompt corrective action" (PCA) provisions of the Federal Deposit Insurance Corporation Improvement Act (FDICIA) of 1991, by all accounts, increased capital adequacy requirements for commercial banks and made more certain that failure to meet them would result in sanctions.

In this second test, our strategy, roughly stated, is to examine the change in merger activity exhibited by large BHCs before and after PCA provisions became relevant. We restrict the sample to those $\mathrm{BHCs}$ that met the pre-PCA capital requirements both before and after the PCA standards became relevant. These conditions are imposed to determine whether BHCs that became constrained only because of the new capital requirements (and not for other reasons that may entail endogeneity bias) decreased their merger activity by more (or increased it by less) than those BHCs that were not constrained by the new

${ }^{9}$ Another example might be an improvement in a local economy that resulted in an increase in both the merger activity and excess capital of BHCs located in the relevant area but that had no or less influence on BHCs not located in the area. This would impart a positive bias to the coefficients of the measures of excess capital in the regressions reported below. To control for this possibility, we include a measure of local economic health in the analysis. 
requirements.

A positive answer to the question of whether constrained BHCs decreased their acquisition activity relative to unconstrained BHCs would be consistent with the hypothesis that "binding" or constraining capital requirements reduce merger activity. More relevant to the question at hand, it would be consistent with the hypothesis that relaxation of regulatory capital requirements, to the extent that they are binding or constraining, would result in an increase in merger activity.

A more formal derivation of the test is presented as follows: Suppose that before the advent of PCA, the relationship between the merger activity of a typical, large BHC and its capitalization can be expressed as:

$$
M_{i}^{b}=\beta_{o}^{b}+\beta_{1} K A D U M^{b}+\beta_{2} X^{b}+\varepsilon_{i}^{b},
$$

where the superscript " $b$ " denotes that the variable or coefficient pertains to the period before PCA, $K A D U M^{b}$ is a binary variable that receives the value of one if capitalization was less than the level at which regulatory capital requirements in that period became binding or constraining, and zero otherwise, and $\varepsilon_{i}^{b}$ denotes the error term. The major feature of this specification is that it allows a discrete difference in merger activity for BHCs that do and do not face binding capital constraints.

We posit the same relationship after PCA, expressed as:

$$
M_{i}^{a}=\beta_{o}^{a}+\beta_{1} K A D U M^{a}+\beta_{2} X^{a}+\varepsilon_{i}^{a},
$$

where the superscript "a" refers to the period after adoption of PCA standards, with all 
variables defined as in (3).

Note that coefficients are presumed to be the same in (3) and (4), consistent with the underlying "natural experiment" rationale for the test, which is that only regulatory capital requirements, and not underlying relationships between acquisition activity and explanatory variables changed between periods. There appears to be little reason to expect changes in regulatory minimums to affect these underlying relationships between merger activity and its determinants. Importantly, $K A D U M^{a}$ is a binary variable that receives the value of one if capitalization is less than the critical value of capitalization under PCA. If this critical value is higher than that which was relevant in the earlier period, then we will observe some BHCs for which $K A D U M^{b}=0$ and $K A D U M^{a}=1$, despite little or no change in capitalization. In other words, there will be some BHCs that were not constrained before the introduction of PCA standards, but became constrained as a result of that introduction.

Subtracting (3) from (4) yields:

$$
M_{i}^{a}-M_{i}^{b}=\left(\beta_{0}^{a}-\beta_{0}^{b}\right)+\beta_{1}\left(K A D U M^{a}-K A D U M^{b}\right)+\beta_{2}\left(X^{a}-X^{b}\right)+\left(\varepsilon_{i}^{a}-\varepsilon_{i}^{b}\right)
$$

If determinants of merger activity other than those associated with a binding capital requirement are either invariant over time, (in which case $X^{a}=X^{b}$ ) or, as with variables reflecting the macroeconomic environment, the same across BHCs over the time period, then the term $\beta_{2}\left(X^{a}-X^{b}\right)$ in (5) is either zero or subsumed into the constant term. Under these conditions, only $\beta_{1}, K A D U M^{a}$, and $K A D U M^{b}$ explain differences between the two groups of BHCs in the change in merger activity before and after PCA. It follows that 
$\left(K A D U M^{a}-K A D U M^{b}\right)=1$ for the case of a BHC that was not constrained by capital requirements before PCA but was constrained afterwards, and that the term $\left(K A D U M^{a}-K A D U M^{b}\right)=0$ for BHCs that were not constrained in either period.

If $\beta_{1}<0$, which is implied if constrained BHCs engage in less merger activity than unconstrained ones, then we have the simple prediction that, of those BHCs believed to be unconstrained by capital requirements prior to $\mathrm{PCA}\left(K A D U M^{b}=0\right)$, the $\mathrm{BHCs}$ that became constrained after the change to tougher capital standards $\left(K A D U M^{a}=1\right)$ should have experienced a greater reduction (or smaller increase) in merger activity than those BHCs that remained unconstrained after the change $\left(K A D U M^{a}=0\right)$. This prediction follows because the only remaining term (except for the constant) in (5), given these assumptions, is: $\beta_{l}\left(K A D U M^{a}-K A D U M^{b}\right)$, and, with $\beta_{l}^{<0}$, this term is negative for banking organizations constrained by PCA and zero for those that are not.

Under the assumptions discussed above, this prediction may be tested with a straightforward comparison of the change in merger activity across the two groups. This test has the benefit of focusing on the effect of an actual past change in capital standards, and it offers well known advantages associated with this "difference in difference" methodology. Among these advantages, all of the numerous differences in BHCs that might influence merger activity and that do not change over the comparison period "cancel out." Further, because the changes in merger activity for the two groups are calculated for the same time period, the effects of macroeconomic and other changes over time (as long as they influence the two groups equally) are fully controlled for. While these simplifying 
assumptions appear reasonable, tests based on full estimations of (5) are also conducted.

\section{Samples, Data, and Key Variables}

Samples employed in the analysis consist of the largest U.S. BHCs (based on total assets as of mid-year 2003) that operated throughout the period under investigation. Two successively larger samples of BHCs that operated between year-end 1991 and mid-year 2003 are used in test 1 (panel data analysis). The more restrictive sample includes the ten U.S. banking organizations that are expected to be required to adopt A-IRB status under the current proposals. These organizations are referred to as the mandatory A-IRB BHCs. The first sample also includes the nine other U.S. BHCs with total assets of at least $\$ 50$ billion as of mid-year 2003, since they are considered most likely to adopt voluntarily the A-IRB approach in the initial implementation phase. The second and larger sample includes the ten mandatory A-IRB BHCs plus all other U.S. BHCs with total assets of at least $\$ 15$ billion as of mid-year 2003. This results in a sample of 38 BHCs and includes a large number of banking organizations that are likely to eventually adopt A-IRB. Analysis is conducted on both samples over two different time periods: a shorter and more recent one covering the years 1998-2002 and a longer one covering the years 1993-2002.

The samples used in test 2 (the natural experiment) are the same as those used in test 1, except that BHCs must have operated between year-end 1986 and mid-year 2003. This requirement causes two BHCs to be dropped because they were not operating during the early part of the period. For reasons discussed below, the years 1987 to 1989 serve as 
the pre-PCA period, while 1991 and 1992 serve as the post-PCA period.

Merger data were obtained from two sources. The SNL Financial Bank Mergers and Acquisitions Database was the primary source for data on deals that were completed after December 31, 1989. The SNL database includes the vast majority of acquisitions of banks (banks and bank holding companies) and thrifts (savings banks, savings and loan associations, and thrift holding companies) that took place during the period, which includes all of the time covered by test 1 (panel study) and the latter part of test 2 (natural experiment).

The SNL database is not used before 1990 because it is not very comprehensive for deals that took place during that time. Therefore, data for this earlier period were collected from another source. Mergers that took place in 1987, 1988, or 1989-the prePCA years needed for test 2-were identified from a database created by staff at the Federal Reserve Board from Federal Reserve Bulletins and reports provided by the Federal Deposit Insurance Corporation (FDIC) and Office of the Comptroller of the Currency (OCC).$^{10}$ This database includes only acquisitions in which each party was either a commercial bank or a BHC that operated a commercial bank. Deals involving a thrift as the acquirer or target were not included. Therefore, to maintain consistency, mergers involving savings banks or savings and loan associations that took place after the adoption of PCA are dropped from the group of mergers identified on the SNL database. This

\footnotetext{
${ }^{10}$ This database was the primary source for two extensive studies of bank merger activity in the United States. See Rhoades (2000) and Rhoades (1996).
} 
requirement has little effect on the set of mergers included in the analysis.

We construct two variables that measure merger activity. The first is the annual number of mergers completed during the relevant period by a BHC. This variable measures the frequency with which a BHC pursued consolidation, not the size of acquisitions. It can be constructed for all years in our analysis and therefore is used for both test 1 and test 2 .

A second merger variable that incorporates the size of the targets acquired by a BHC is also used for test 1 . Data on the amount of banking assets acquired are available for all years included in test 1 and are used to construct a measure of the relative magnitude of acquisition activity that was conducted by each BHC in the sample. Specifically, the aggregate amount of banking assets acquired in a given year is divided by the BHC's asset level at the start of the year. By dividing by the BHC's total assets, we account for the size of that banking organization.

Capital ratios are constructed with data from the Y-9C report, which is filed quarterly by each BHC with the Federal Reserve Board and contains extensive accounting information on the organization. Creating variables that measure the extent to which BHCs faced capital constraints involves several challenges. First, during the full time period for which data are required (1986-2002), two distinct sets of capital requirements were in effect. Therefore, the capital ratios that are constructed must be those that were relevant at the time.

Capital requirements during the late-1980s predated the implementation of Basel I 
and its associated risk-based capital rules. At the time, BHCs had to satisfy two

requirements. First, the ratio of primary capital to assets had to be at least 5.5 percent and the ratio of total capital to assets had to be at least 6 percent. ${ }^{11}$ We create variables that measure both the primary and total capital ratios that are consistent with these regulatory requirements.

The original Basel capital accord, or Basel I, was approved in 1988 and fully implemented by 1992. This accord established a new set of capital requirements that attempted to take risk into account. More specifically, less capital had to be held against assets that were considered safer, such as residential mortgages and inter-bank loans, as well as government and agency securities. BHCs had to satisfy two risk-based capital requirements and one leverage requirement. The ratio of tier 1 capital to risk-weighted assets had to be at least 4 percent, the ratio of total capital to risk-weighted assets had to be at least 8 percent, and tier 1 capital to average tangible assets had to be at least 4 percent. For each year that the Basel I requirements were in effect, we construct variables that correspond to each of these three capital ratios.

Legal limits represent the lowest level of capital that a BHC can maintain before

${ }^{11}$ Primary capital for a bank holding company consists of common stock, perpetual preferred stock, surplus (excluding surplus relating to limited-life perpetual stock), undivided profits, contingency and other capital reserves, mandatory convertible instruments, allowance for possible loan and lease losses (exclusive of allocated transfer risk reserves), minority interest in equity accounts of consolidated subsidiaries, and perpetual debt instruments. Total capital consists of primary and secondary capital. This latter component includes limited-life preferred stock, as well as bank subordinated notes and debentures and unsecured long-term debt of the parent company and its non-bank subsidiaries. 
violating regulatory requirements. However, as mentioned, BHCs are likely to prefer to hold a capital buffer above those regulatory limits for a variety of reasons. First, there are tangible benefits to being considered well or strongly capitalized. During the 1990 s, the implementation of PCA standards meant that banks that maintained capital ratios below certain thresholds faced increased regulatory intervention despite the fact that their capital ratios exceeded regulatory minimums. Although PCA does not directly apply to BHCs, it is relevant, because it applies to their bank subsidiaries. To be considered well-capitalized under the requirements of PCA, a bank must have a ratio of tier 1 capital to risk-weighted assets of at least 6 percent, a ratio of total capital to risk-weighted assets of at least 10 percent, and tier 1 capital to average tangible assets of at least 5 percent.

In the late 1980s, prior to Basel I rules, the Federal Reserve Board had established that 7 percent was an important level for the total capital ratio. BHCs with total capital that exceeded 7 percent of assets were considered adequately capitalized and faced less intense monitoring and a lower likelihood of supervisory actions than BHCs with ratios below 7 percent, but above 6 percent, the required minimum.

Another reason that BHCs may want to hold capital above Basel I or even the PCA regulatory limits is for protection against downturns in the business cycle and unanticipated events. Additional capital may also be desirable because it would provide BHCs with flexibility that could be used to pursue potentially profitable opportunities such as acquisitions or other types of expansion. Moreover, a buffer may be desirable so that losses do not restrict the BHC's ability to engage in certain businesses. Of course, 
still another reason that BHCs may maintain capital ratios that exceed regulatory minimums is that the level of capital dictated by the market may exceed the level that would be held because of regulatory requirements.

To make the relationship between excess regulatory capital and merger activity more explicit, measures of $\mathrm{BHC}$ capitalization are expressed in terms of excess regulatory capital, which is calculated as actual capital ratios less some critical level based on regulatory requirements or standards. The critical levels chosen for this purpose will be those that must be exceeded to be considered strongly capitalized. More specifically, we use the three ratios required for a bank to be considered-well capitalized under PCA (tier 1 capital to risk-weighted assets of 6 percent, total capital to risk-weighted assets of 10 percent, and tier 1 capital to average tangible assets of 5 percent) for analysis of the years since 1990 and the total capital ratio level (7 percent of assets) required to avoid additional scrutiny in the late 1980s. Although no level for a strong level of the primary capital ratio was defined by the regulator prior to 1991, we use 6.5 percent (the regulatory minimum of 5.5 percent plus 1 percentage point) as an estimate for a primary capital ratio that would be considered a sign of a strong BHC. Table 1 presents a summary of the various capital ratios, requirements, and variables that are relevant for different time periods.

For each $\mathrm{BHC}$, we construct a variable that measures the overall constraint faced by the $\mathrm{BHC}$ by taking the minimum of all the measures of excess regulatory capital that were relevant during the year. Because BHCs must satisfy all the capital requirements in effect at a given time, the ratio that reflects the weakest, or most binding, actual capital 
position is the one that is likely to be most relevant for the BHC. We recognize that simply taking the lowest value is imprecise. For example, ratios are based on different numerators, and, in recent years, different denominators. Nonetheless, we believe that the magnitude of the smallest excess capital measure provides a reasonable proxy for the extent of capital constraints faced by a BHC. For test 1 , we measure excess capital at the beginning of each year under investigation (1993-2002 or 1998-2002), and for test 2, we measure it at the beginning of 1987 for the pre-PCA period and at the beginning of 1991 for the post-PCA period.

In short, we take the smallest difference between each of the capital ratios from among the relevant set of regulatory ratios and the value required to be considered strongly capitalized. While not adjusted for individual levels of BHC risk and risk tolerance or for idiosyncratic needs to meet capital requirements, we nonetheless believe that our measure of excess regulatory capital roughly captures the degree to which a BHC faced regulatory capital constraints.

\section{Results}

Before considering the results of our two tests, we note first another finding that is relevant to the question of the Basel II proposal and merger activity. Examination of previous mergers indicates that banking organizations that were acquired by the large BHCs in our sample tended to have larger capital ratios than their acquirers. This finding is relevant to concerns about A-IRB, because if BHCs desire to acquire banking 
organizations with greater capitalization, then a bifurcated system of regulatory capital may encourage them to increase the extent to which they acquire other banking organizations.

The observed difference in the capitalization of large acquirers and their targets, however, may simply result from the fact that large banking organizations tend to have lower capital ratios than smaller ones, perhaps because market determined capital requirements tend to be greater for smaller organizations than for larger ones, and because larger organizations disproportionately acquire smaller ones. Moreover, as discussed earlier, prior studies have consistently found that banks with lower levels of capital are more likely to be acquired than better capitalized banks, suggesting that the desire to obtain a large amount of capital is not a strong motive in many bank acquisitions. In any event, the two tests that we conduct provide a more thorough and rigorous examination of the question of whether changes in regulatory capital requirements might be expected to influence merger activity.

Test 1. In the first type of test conducted, we estimate, for two different samples of BHCs and for two different time periods, the relationship between a BHC's merger activity and its excess capital, defined as the minimum of the difference between each of three actual capital ratio measures and that level of those ratios required to be considered strongly capitalized. Table 2 provides definitions of the independent variables used in these estimations.

Because many of the BHCs in the sample made no acquisitions during at least 
some of the years in which they are observed, each of the two dependent variables used to measure annual merger activity (the number of acquisitions and the ratio of banking assets acquired to the assets of the acquirer) receive the value of zero for many observations.

Because of the well-known violation of OLS assumptions that this entails, other estimation procedures must be used. Since the number of annual acquisitions made by a $\mathrm{BHC}$ is a count of the number of occurrences of an event, we use negative binomial maximum-likelihood regression when this variable is employed to measure merger activity. ${ }^{12}$ Since the ratio of acquired banking assets to the assets of the acquirer may be thought of as a continuous variable that is censored at zero, we use Tobit maximumlikelihood regressions when this variable is employed to measure merger activity.

Each reported regression includes as an explanatory variable the BHC's expense ratio (expense ratio), calculated for the previous year as total noninterest expenses divided by the sum of total noninterest income and net interest income. This rough, but widely used, measure of a BHC's efficiency is included as an explanatory variable because it is often asserted that greater efficiency is associated with greater acquisition activity, as more efficient firms frequently acquire less efficient ones. ${ }^{13}$ A negative and significant coefficient on this variable would be consistent with this hypothesis, because more

\footnotetext{
${ }^{12}$ Because assumptions underlying the more common Poisson maximum-likelihood regressions could be rejected, this more general estimation procedure was chosen. See chapter 19 of Wooldridge (2002) for an extensive discussion on these regression models.

${ }^{13}$ Akhavein, Berger, and Humphrey (1997) and Vander Vennet (1996) report evidence consistent with this.
} 
efficient firms have lower values of this expense ratio.

To account for differences in the economic conditions in which BHCs in the sample operate, we employ the annual change in housing prices, collected from a weighted repeat sales index (the House Price Index) produced by the Office of Federal Housing Enterprise Oversight. Price changes are measured at the state level and over the same year as merger activity. For BHCs with banking assets in more than one state, a weighted average of these state-specific measures is used, with each state's share of the BHC's total deposits used as the weights. ${ }^{14}$

For each type of estimation, results using two different functional forms are presented, conforming to specifications (1) and (2) above. The first employs as an explanatory variable excregcap, which is a continuous measure of excess regulatory capital, measured, as described above, as the minimum difference between each of the three observed capital ratios and that level of each ratio required to be considered well capitalized under PCA. The second replaces this variable with two binary variables indicating different ranges of excregcap observed for the BHC. The variable excregcap(1-2) indicates that the BHC's excess regulatory capital, measured as described above, is between 1 percentage point and 2 percentage points, while excregcap $(>2)$ is similarly defined for BHCs that have excess regulatory capital of at least 2 percentage

\footnotetext{
${ }^{14} \mathrm{We}$ also account for local economic conditions by including a variable that measures the average unemployment rate in the state or states in which a BHC operates. Results (not reported) using this variable are the same as those obtained using the annual change in housing prices.
} 
points. BHC and year combinations in which the minimum capital differential is less than 1 percentage point represent the omitted category.

Tables 3 and 4 report regression results obtained for the 1998-2002 period, and tables 5 and 6 report the results of equivalent estimations conducted for the longer 19932002 period. All reported regressions include year fixed effects (reported only in tables 3 and 4 for reasons of space) and $\mathrm{BHC}$ fixed effects (not reported in any tables for reasons of space). Tables 3 through 6 each presents four different estimations, organized into two pairs. The first pair reports the results of negative binomial maximum-likelihood regressions when the number of acquisitions serves as the dependent variable, while the second pair present the results of Tobit maximum-likelihood regressions when the ratio of acquired banking assets to assets of the acquirer serves as the dependent variable.

Consider first table 3, which presents results obtained for the period 1998-2002 for a sample consisting of the ten mandatory A-IRB BHCs and the nine other BHCs with total assets of at least $\$ 50$ billion as of mid-year 2003. This sample may be the most immediately relevant to the Basel II proposal, since it is composed specifically of those BHCs whose regulatory capital requirements would be the most likely to be directly affected by the proposal. Of the nineteen BHCs in this group, four are excluded from these estimations because they made no acquisitions during the period. ${ }^{15}$

${ }^{15}$ These observations are dropped, because the fixed-effects statistical model that is used in the empirical analysis requires that, for a given $\mathrm{BHC}$, acquisition activity exhibit some variation over time. 
The finding of positive and statistically significant coefficients on the measures of excess regulatory capital would be consistent with the hypothesis that greater excess regulatory capital enabled or induced BHCs to increase acquisition activity. However, the coefficients reported in 3 are not statistically significant. Indeed the coefficients on excregcap, the continuous measure of excess regulatory capital, are negative and insignificant. The coefficients on the binary variable excregcap(1-2) are positive when either the number of mergers or the ratio of assets acquired to total assets is used to measure merger activity, and the coefficient on excregcap $(>2)$ is positive when the ratios of assets acquired to total assets is used, but these coefficients are also not statistically significant, both individually and jointly, with either measure of merger activity.

The coefficients on expratio are negative, consistent with the hypothesis that less efficient BHCs (i.e., those with higher expense ratios) are less likely to acquire other banking organizations, but they are not statistically significant. The coefficients on hpchange, the change in housing prices during the year, are positive, as might be expected if a better state economy is associated with a greater tendency for BHCs to acquire other banking institutions, but they are also not statistically significant. The coefficients on the year binary variables are negative and, in most cases, statistically significant, reflecting the fact that 1998, the year representing the omitted category, saw a greater amount of merger activity than later years in the period.

Our inability to find a statistically significant relationship between merger activity and excess regulatory capital may reflect the possibility that the level of capitalization 
required by the market is, for the most part, greater than that required by regulation, with no relationship between regulatory requirements and merger activity the result. However, this lack of statistical significance may also reflect the small size of the sample, chosen to contain only those BHCs that are the most likely to be required to adopt or the most likely to adopt voluntarily the A-IRB approach.

Table 4 reports the results of the same regressions, run on a larger sample obtained by lowering the size threshold from $\$ 50$ billion to $\$ 15$ billion in total consolidated assets as of mid-year 2003. The result is an increase in the number of BHCs in the analysis from 15 to 33 and an increase in the number of year-BHC observations from 75 to 165 . For this larger sample, the coefficients on all measures of excess regulatory capital are positive, consistent with the hypothesis that excess regulatory capital induces or enables BHCs to engage in more acquisition activity, but again, none are statistically significant. The estimated coefficients on excregcap (1-2) and excregcap $(>2)$ are jointly insignificant as well.

The coefficients on expense ratio are negative, consistent with the hypothesis that less efficient banking organizations exhibit less of a tendency to acquire other organizations, and these coefficients are highly significant when the ratio of assets acquired to total assets is used as the measure of merger activity. The coefficients on hpchange are not statistically significant, while the coefficients of the year binary variables are all negative and, in most cases, highly significant, reflecting the general decline in merger activity occurring after 1998. 
Tables 5 and 6 report estimates for regressions equivalent to those reported in tables 3 and 4, except that they employ panel data sets that extend from 1993 to 2002 instead of from 1998 to $2002 .{ }^{16}$ Table 5 reports these results for a sample consisting only of BHCs with greater than $\$ 50$ billion in consolidated assets (which includes all mandatory A-IRB BHCs). Again, all coefficients on variables that measure the degree of excess regulatory capital are positive, but not statistically significant. The coefficients on the two binary excess capital variables are also jointly insignificant.

The coefficients on expratio are all negative and, for this sample, highly significant in every case, consistent with the hypothesis that more efficient banking organizations exhibit a greater tendency to acquire other banking organizations. The coefficients on hpchange are not statistically significant. Year fixed effects in the case of this longer panel are not shown for reasons of space.

Table 6 reports the results of equivalent regressions when the sample is expanded to include BHCs with greater than \$15 billion in consolidated assets as of mid-year 2003. Because of the many years and BHCs included as observations, this sample is the largest of those for which results are reported, and here, we do find statistically significant positive coefficients on the measures of excess regulatory capital when the number of mergers is the measure of merger activity, but not when the ratio of acquired assets to total

\footnotetext{
${ }^{16}$ Note that the samples analyzed over the 1993-2002 period contain more BHCs than the samples analyzed over the shorter 1998-2002 period, because, for this longer panel, fewer BHCs were omitted as a result of making no acquisitions during the period. Only two BHCs made no acquisitions between 1993 and 2002.
} 
assets is used as the measure. In this latter case, the coefficients on the binary capital variables are not jointly significant either. Also in the case of this sample, the coefficients on expense ratio are negative and statistically significant in most cases, while the coefficients on hpchange are not significant.

As previously noted, one possible route by which excess regulatory capital could affect merger activity is by first influencing return on equity and firm valuation. We examine this route empirically by including lagged return on equity both as an additional variable in the regression equation (with lagged measures of excess regulatory capital) and as a replacement for measures of excess regulatory capital. In both cases, results (not reported) indicate a positive relationship between return on equity and subsequent acquisition activity, as measured by the number of deals, when estimated over the ten-year period. However, results are not significant when regressions are estimated over the fiveyear period and are mixed when estimated over the ten-year period with merger activity measured by the ratio of acquired assets to acquirer assets. Thus, results are only weakly consistent with the argument that regulatory capital standards influence merger activity by affecting return on equity and bank valuation. Importantly, the results are also consistent with various alternative explanations of the relationships between excess regulatory capital, return on equity, and merger activity. ${ }^{17}$

${ }^{17}$ The interpretation of results is complicated by including return on equity as an additional explanatory variable. The reason is that, with inclusion of a measure of return on equity in the regression, the coefficient of excess regulatory capital would capture only the effect of excess regulatory capital on merger activity that would exist with return on 
Summarizing the results reported in tables 3 through 6 , we find that coefficients on measures of excess regulatory capital are generally positive, consistent with the hypothesis that excess regulatory capital induces or enables BHCs to increase their level of merger activity, but in most cases are statistically insignificant. Indeed, such coefficients are statistically significant only when the largest sample is employed, and then only for the case in which merger activity is measured by the number of annual acquisitions.

Despite these generally weak regression results, it is still possible that the relationship between excess regulatory capital and BHC merger activity is quantitatively important, based on the magnitude of estimated coefficients. To address this issue, we estimate the likely range of the quantitative impact of adoption of the A-IRB approach on merger activity by combining coefficient estimates with estimates of changes in excess regulatory capital that might result from adoption of A-IRB.

The Third Quantitative Impact Study (QIS 3) was conducted by the Basel Committee on Banking Supervision to understand the possible effects that the Basel II proposals (as of late 2002) might have on capital levels across participating banks. ${ }^{18}$

equity held constant. Thus, for example, the inclusion of return on equity as an additional explanatory variable would leave no observable effect of excess regulatory capital on merger activity if excess regulatory capital only affects merger activity through its influence on the return on equity. It should also be noted that in any model that includes return on equity, the empirical relationship between return on equity and merger activity would reflect all aspects of the underlying relationship between the two measures, not just those related to the effect of excess capital on return on equity.

${ }^{18}$ The evolution of the Basel proposal, of course, implies that the QIS 3 may not be a good indicator of the effect of the present proposal. Another quantitative impact study is 
Based on data for 22 U.S. BHCs, the QIS 3 estimated that adoption of A-IRB would, by reducing certain risk weights, lead to an average reduction in total risk-weighted assets (RWA) of 6 percent. This change would have the effect of raising the ratios of tier 1 to RWA and total capital to RWA. A change in RWA has no effect on the leverage ratio (total capital to average tangible assets), because the denominator is not based on RWA.

We calculate the three relevant regulatory capital ratios-tier 1 capital to RWA, total capital to RWA, and tier 1 capital to average tangible assets-for each of the 38 BHCs in the sample using data from June 30, 2003. We also estimate the value of those ratios under the A-IRB approach by assuming that RWA would be 6 percent lower than the level reported as of that date. Then, for both sets of the three ratios, we compute the difference between each of the ratios and the minimum needed to be considered well capitalized under PCA standards (see table 1). Next, for both the standard and A-IRB approach, we take the minimum of the three differences. Finally, we subtract the excess capital figure computed under current capital rules from the excess capital figure obtained under the AIRB approach to get an estimate of the change in excess regulatory capital (expressed as a ratio) that a $\mathrm{BHC}$ would experience with the adoption of the $\mathrm{A}-\mathrm{IRB}$ approach. It should be noted that this final figure will be 0 if the $\mathrm{BHC}$ were constrained by the leverage ratio under both capital approaches, since the leverage ratio would be unaffected by adoption of A-IRB.

planned for later in 2004. 
On average, we find (using QIS 3 results) that adoption of A-IRB would result in an increase in a BHC's excess regulatory capital (expressed as a ratio) of 0.31 percentage points. However, it should be noted that this estimate assumes that every BHC in the sample experienced an identical change in risk-weighted assets equal to the average. In actuality, however, the change in risk-weighted assets following adoption of A-IRB should vary across BHCs. Although not accounting for this variation should affect our estimates of the change in excess regulatory capital, the results of the exercise should not be substantially influenced, because we are estimating the likely range of changes in merger activity, which is rather general.

In order to assess the economic meaning of an increase in excess regulatory capital of 0.31 percentage points, we employ the regression coefficient on excregcap, as well as previous levels of BHC merger activity. ${ }^{19}$ Calculations of the range of likely changes in acquisition activity are based on the smallest and largest estimated coefficients on excregcap, because they generate the most extreme changes in merger activity that can be predicted from regression results.

The largest coefficient estimated for the number of deals is 0.19 (table 4), and it implies that the average number of mergers conducted by a BHC would increase by 6.1

\footnotetext{
${ }^{19} \mathrm{We}$ do not examine the change in merger activity implied by coefficients on excregcap (1-2) and excregcap $(>2)$ because we estimate that the values of these binary variables following adoption of A-IRB would change for very few BHCs in our sample.
} 
percent, given an increase in excess regulatory capital of 0.31 percentage points. ${ }^{20}$ The smallest coefficient estimate is -0.087 (table 3 ) and it corresponds to a decrease in the number of acquisitions of 2.7 percent. These percent increases translate into very modest projected changes in merger activity. The average $\mathrm{BHC}$ in the full sample of 38 banks conducted 1.74 deals per year between 1993 and 2002, which is greater than the 19982002 average for the full sample or any of the averages for the smaller sample of very large BHCs. Given this average number of deals, a 6.1 percent increase would mean an increase in the average annual number of mergers of only 0.1 acquisitions per large $\mathrm{BHC}$, and a 2.7 percent decrease would mean 0.05 fewer acquisitions per year for each large BHC.

With respect to the ratio of acquired banking assets to total $\mathrm{BHC}$ assets, the largest coefficient is 0.049 (table 4) and the smallest one is -0.022 (table 3 ). Respectively, these estimates imply changes in the average value of acquired assets to acquirer assets of 1.5 percentage points and -0.7 percentage points following a 0.31 percentage point jump in excess regulatory capital. ${ }^{21}$

Several caveats suggest that these estimated changes in BHC merger activity that would follow adoption of the A-IRB approach should be viewed as rough, back-of-the-

${ }^{20}$ For the negative binomial regression, the percentage increase in the number of mergers for a given change in excess capital ( $\Delta$ excregcap) can be computed as $\left(100 \times e^{(\beta)(\Delta \text { excregcap })}-100\right)$, which in this case equals $100 \times e^{(0.19)(0.31)}-100$.

${ }^{21}$ The percentage point increase in the ratio of acquired assets to acquirer assets for a given change in excess capital ( $\Delta$ excregcap) can be computed simply as $100 \times \beta \times \Delta$ excregcap. 
envelope calculations. First, the analysis is static and does not take into account the effect of portfolio changes that could accompany adoption. If BHCs increase the relative share of their assets held in categories that would receive lower risk weights, then the increase in excess regulatory capital could be greater than the estimate of 0.31 percentage points. Second, the data used to estimate changes in RWA are based on QIS 3, which analyzed the effect of the Basel II proposal that was current at the time of the study (late 2002/early 2003). The regulatory capital rules that are ultimately adopted are likely to differ from those used in QIS 3. Finally, we have noted that the estimated change in excess regulatory capital incorporated in this analysis is based on the average change in risk-weighted assets and does not take into account the wide range of possible changes that individual BHCs may experience.

In summary, our estimates suggest that the likely change in the number of acquisitions that would follow adoption of the A-IRB capital approach would fall within a narrow range, and that the number of acquisitions would be unlikely to change much following adoption. This result is especially notable because the only significant results obtained in test 1 are for the case in which acquisition activity is measured by the number of deals. Estimates of the change in the ratio of acquired assets to BHC assets includes more extreme values and the likely range is therefore larger. However, all of these estimates are based on statistically insignificant coefficients.

Test 2. Tables 7 and 8 present the results of t-tests that analyze the effect on merger activity of generally tighter capital requirements brought about by the adoption of 
PCA capital standards. In these two tables, merger activity before PCA is measured as the average number of mergers per year during the period 1987-1989. Merger activity after the time that the requirements of PCA should have been foreseen, assumed to be the beginning of 1991, is measured as the average number of mergers per year for the period $1991-1992 .^{22}$

Only BHCs judged to be relatively unconstrained by the capital requirements in effect prior to the advent of PCA (the "old standards") are included in the comparisons. Such BHCs are defined as those that met the requirement for being "strongly capitalized" (primary capital ratio of at least 6.5 percent and total capital ratio of at least 7 percent) as of December 31, 1986, the start of our pre-PCA period. In addition, we require that the primary capital and total capital ratios of sample BHCs as of December 31, 1990, the start of our post-PCA period, also exceed 6.5 percent and 7 percent, respectively. Requiring sample BHCs to be well-capitalized under the "old standards" at the start of both periods increases the likelihood that the change in acquisition activity undertaken by a BHC over the analysis period is affected largely by the new PCA standards, and is not heavily influenced by any underlying weakness in the BHC's capital position that would have

\footnotetext{
${ }^{22}$ Although PCA was enacted in December 1991 and fully implemented at the end of 1992, we believe that 1991-92, which took place before PCA became legally binding, is the appropriate period to use as the time that PCA standards first became relevant. The data show that in 1991 sample BHCs with less excess regulatory capital, as measured with the ratios relevant under PCA, increased their excess regulatory capital by more than sample BHCs with greater excess regulatory capital measured with those ratios. This behavior suggests that the standards that would become legally effective at the end of 1992 were already affecting BHCs in 1991. Nonetheless, the results of the analysis are similar if 1992-93 is used as the post-PCA period.
} 
affected merger activity even if standards had not been increased.

BHCs are split into two groups-those that became constrained by the "new standards" introduced by PCA and those that remained unconstrained under these standards. In the post-PCA period, a BHC is classified as constrained if it fails to meet any of the requirements for being well capitalized under PCA (see table 1) as of December 31, 1990. BHCs that meet all three of these requirements are counted as unconstrained after the change to the new capital regime. Clearly, other definitions of what constitutes a binding capital constraint are possible, and we discuss below the results of tests that employ alternative definitions.

Table 7 reports the results of this test for the sample of sixteen mandatory A-IRB BHCs and other BHCs with consolidated assets greater than $\$ 50$ billion (as of mid-year 2003) that met the definition of being unconstrained under the "old standards" as of yearend 1986 and year-end 1990. The first row indicates that for those BHCs that became constrained by PCA capital standards (nine BHCs), mergers per year declined from an average of 1.63 during the period 1987-1989 to .61 during the 1991-1992 period. The second row indicates that for the group of BHCs judged not to have become constrained by PCA standards (seven BHCs), mergers actually increased slightly, from 1.33 per year during the 1987-1989 period to 1.50 per year in the period 1991-1992. Perhaps the most relevant number reported in table 7 is the "difference in difference" reported in the third column of the third row. This figure shows that BHCs that became constrained participated in 1.19 fewer mergers per year, on average, than would have been the case 
had they not become constrained, assuming their merger activity changed after the introduction of PCA in the same way as the group that remained unconstrained. Although the difference between the two groups of BHCs is clearly consistent with the hypothesis that the imposition of binding capital requirements would cause merger activity to decline, the t-statistic calculated for this difference, and reported in the third column of the fourth row, is only -1.46 , indicating that this difference is not statistically significant at levels traditionally employed to reject null hypotheses (in this case that there is no difference between the two groups).

Table 8 reports the results of an equivalent test conducted using a larger sample obtained by including those BHCs that had at least $\$ 15$ billion in consolidated assets as of mid-year 2003. In this sample, those BHCs that became constrained by the requirements of PCA (eleven BHCs) reduced the number of acquisitions that they made annually from 1.48 in the period 1987-1989 to .54 in the 1991-1992 period. The seventeen BHCs in the sample that did not become constrained by the requirements of the new capital standard also exhibited a reduction in average annual acquisitions, from 1.08 in the earlier period to .76 in the later period. The "difference in difference" of -.63 indicates that BHCs that became constrained by PCA participated, on average, in .63 fewer mergers per year than would have been the case had they exhibited the same change as did those BHCs that did not become constrained. The t-statistic of -1.18 registered for this difference indicates that for this sample as well, this difference is not statistically significant.

The results obtained in test 2 appear to be robust, as we conducted a number of 
alternative analyses and obtained consistent findings. The results of these additional analyses are discussed, but not reported. Results obtained using higher standards to differentiate whether a BHC is classified as capital constrained or not under the new PCA standards indicate no significant differences in the change in merger activity of the two groups of BHCs. In one of these alternative tests, we classified a BHC as constrained if any of its relevant capital ratios were less than the PCA standard plus 0.5 percentage points, and in another alternative, we used the PCA standard plus 1 percentage point to distinguish between constrained and unconstrained BHCs. Results were similar to those reported in tables 7 and 8, which present results based on PCA standards (with no additional cushion) as the level used to classify BHCs.

We also conducted analyses on an expanded sample of 54 BHCs that operated between December 31, 1986 and December 31, 1993 and that held assets of at least $\$ 5$ billion as of December 31, 1986. Of these organizations, 45 were unconstrained under the "old standards." Results based on this group also fail to reject the hypothesis of no difference in the change in acquisition activity between those BHCs that became constrained by PCA standards and those that did not. Further, regression analyses that control for other variables that might influence the observed change in a BHC's merger activity, as derived in (5) above, were conducted and found to yield similar, statistically insignificant results. Finally, as noted (see footnote 22), results are similar when the postPCA period is defined as 1992 and 1993, although more BHCs are unconstrained by PCA standards in this later period. 


\section{Summary and Conclusion}

This paper examines empirically the question of whether the advanced internal ratings-based (A-IRB) approach employed by certain large banking organizations to determine their regulatory capital requirements, as provided for in the Basel II proposal, would be likely to lead those banking organizations to increase their acquisition activity.

Concerns that acquisition activity would increase following adoption of A-IRB in the United States by a small number of large banking organizations stem from two consequences of using the new approach. Arguments based on these consequences can be usefully designated as "excess regulatory capital" and "relative capital advantage" arguments. "Excess regulatory capital" arguments focus on the additional excess regulatory capital that would result from a reduction in an A-IRB adopter's capital requirements as the driver of greater acquisition activity. Arguments based on the "relative capital advantage" cite the disparity in capital requirements that would exist between BHCs using the A-IRB approach and those that would not as the force fueling merger activity.

Because we cannot examine the effects of past reductions in capital requirements that affect some organizations but not others, we conduct two less definitive, but nonetheless informative, tests. The first uses recent data to determine whether large banking organizations with greater excess regulatory capital exhibited a greater tendency to subsequently acquire other banking organizations. The second examines whether the generally higher capital requirements resulting from adoption of "prompt corrective 
action" standards in the early 1990s (the last time capital requirements were substantially changed) resulted in a relative reduction in merger activity on the part of those large banking organizations most severely affected by the policy.

Both of these tests are most relevant to "excess regulatory capital" arguments for increased acquisition activity. Of relevance to "relative capital advantage" arguments, however, we note that a substantial number of studies do not support a major implication of the arguments.

On the whole, we do not find convincing evidence either that past changes in excess regulatory capital or that past changes in capital standards had substantial effects on merger activity. Estimated coefficients and observed differences have signs consistent with the concern that a reduction in regulatory capital requirements for large banking organizations would result in increased merger activity on their part. However, results of the two tests are, with a few exceptions, statistically insignificant, and, in cases where results are statistically significant, quantitative magnitudes are small. 


\section{REFERENCES}

Amel, D. and S.A. Rhoades. "Empirical Evidence on the Motives for Bank Mergers," Eastern Economic Journal, 15 (January-March 1989) pp. 17-27.

Akhavein, J.D., A.N. Berger, and D.B. Humphrey. "The Effects of Megamergers on Efficiency and Prices: Evidence from a Bank Profit Function," Review of Industrial Organization 12 (February 1997) pp. 95-139.

Berger, A.N., R.S. Demsetz, and P.E. Strahan. "The Consolidation of the Financial Services Industry: Causes, Consequences, and Implications for the Future," Journal of Banking and Finance 23 (1999) pp. 135-194.

Group of Ten. "Report on Consolidation in the Financial Sector," January 2001.

Hancock, D. and J.A. Wilcox. "Bank Capital and Portfolio Composition," Working Paper, Federal Reserve Board (2002).

Hannan, T.H. and S.A. Rhoades. "Acquisition Targets and Motives: The Case of the Banking Industry," The Review of Economics and Statistics 69 (February 1987) pp76-74.

Heckman, J. "Sample Selection Bias as a Specification Error," Econometrica 47, (1979) pp. 153-161.

Houston, J.F., C.M. James, and M.D. Ryngaert. "Where do Merger Gains Come From? Bank Mergers from the Perspective of Insiders and Outsider," Journal of Financial Economics 60 (2001) pp. 285-331.

Jones, D. "Emerging problems with the Basel Capital Accord: Regulatory capital arbitrage and related issues," Journal of Banking and Finance 24 (2000) pp. 35-58.

Moore, R.R. "Bank Acquisition Determinants: Implications for Small Business Credit," Working paper, Federal Reserve Bank of Dallas (April 197).

O'Keefe, J.P. "Banking Industry Consolidation: Financial Attributes of Merging Banks" Banking Review (Fall 1996)

Rhoades, S.A., "Bank Mergers and Industrywide Structure, 1980-94," Board of Governors of the Federal Reserve System, Staff Study 169, January 1996. 
Rhoades, S.A., "Bank Mergers and Banking Structure in the United States, 1980-98," Board of Governors of the Federal Reserve System, Staff Study 174, August 2000.

Vander Vennet, R. "The Effects of M\&As on the Efficiency and Profitability of EC Credit Institutions," Journal of Banking and Finance 20 (1996) pp. 1531-58.

Wheelock, D.C., and P.W. Wilson. "Why Do Bank Disappear? The Determinants of U.S. Bank Failures and Acquisitions," Review of Economics and Statistics 82 (February 2000) pp.127-138.

Wooldridge, J.M. Econometric Analysis of Cross Section and Panel Data (2002)

Cambridge: The MIT Press. 
Table 1

Capital Measures

\begin{tabular}{|l|l|c|c|l|}
\hline & $\begin{array}{l}\text { Relevant } \\
\text { years }\end{array}$ & $\begin{array}{c}\text { Regulatory } \\
\text { minimum }\end{array}$ & $\begin{array}{c}\text { Minimum for } \\
\text { "strongly" } \\
\text { capitalized }\end{array}$ & $\begin{array}{l}\text { Source of definition for } \\
\text { "strongly" capitalized }\end{array}$ \\
\hline $\begin{array}{l}\text { Primary capital to } \\
\text { total assets* }\end{array}$ & $1987-1989$ & $5.5 \%$ & $6.5 \%$ & $\begin{array}{l}\text { Same mark-up that is used } \\
\text { with total capital }\end{array}$ \\
\hline $\begin{array}{l}\text { Total capital to total } \\
\text { assets* }\end{array}$ & $1987-1989$ & $6.0 \%$ & $7.0 \%$ & $\begin{array}{l}\text { Top total capital zone } \\
\text { established in Federal } \\
\text { Reserve System } \\
\text { regulations }\end{array}$ \\
\hline $\begin{array}{l}\text { Tier } 1 \text { capital to risk- } \\
\text { weighted assets }\end{array}$ & $1990-2002$ & $4.0 \%$ & $6.0 \%$ & $\begin{array}{l}\text { Prompt corrective action } \\
\text { standards }\end{array}$ \\
\hline $\begin{array}{l}\text { Total capital to risk- } \\
\text { weighted assets }\end{array}$ & $1990-2002$ & $8.0 \%$ & $10.0 \%$ & $\begin{array}{l}\text { Prompt corrective action } \\
\text { standards }\end{array}$ \\
\hline $\begin{array}{l}\text { Tier } 1 \text { capital to total } \\
\text { assets }\end{array}$ & $1990-2002$ & $4.0 \%$ & $5.0 \%$ & $\begin{array}{l}\text { Prompt corrective action } \\
\text { standards }\end{array}$ \\
\hline
\end{tabular}

*The ratios of primary capital to total assets and total capital to total assets are also computed for 1990 in order to identify bank holding companies that were affected by the advent of prompt corrective action standards, but that did not experience a substantial weakening in capitalization under the standards relevant before prompt corrective action. 
Table 2

Regression Variable Definitions

\begin{tabular}{|l|l|}
\hline Variable & Definition \\
\hline excregcap & $\begin{array}{l}\text { The "excess capital" exhibited by the BHC at the beginning of the year for } \\
\text { which merger activity is observed. Since, for the periods examined, } \\
\text { specified values of three different types of capital ratios had to be } \\
\text { exceeded to be considered well capitalized, this variable measures the } \\
\text { smallest of the differences between the observed BHC's capital ratio and } \\
\text { that level required to be considered well capitalized under prompt } \\
\text { corrective action. }\end{array}$ \\
\hline excregcap(1-2) & $\begin{array}{l}\text { A binary variable indicating that excregcap is between 1 and 2 percentage } \\
\text { points above the regulatory minimum required to be considered well } \\
\text { capitalized. }\end{array}$ \\
\hline excregcap( $>2)$ & $\begin{array}{l}\text { A binary variable indicating that excregcap is 2 or more percentage points } \\
\text { above the regulatory minimum to be considered well capitalized. }\end{array}$ \\
\hline expense ratio & $\begin{array}{l}\text { The "expense ratio" exhibited by the BHC during the year previous to the } \\
\text { year for which merger activity is observed, defined as BHC noninterest } \\
\text { expenses, divided by the sum of noninterest income and the difference } \\
\text { between interest income and interest expenses. }\end{array}$ \\
\hline hpchange & $\begin{array}{l}\text { Weighted average of the percent change in housing prices in the states in } \\
\text { which each BHC operates, with BHC-specific state deposit shares used to } \\
\text { calculate the weights. }\end{array}$ \\
\hline
\end{tabular}


Table 3

The Relationship Between Merger Activity and "Excess Regulatory Capital" for Mandatory A-IRB BHCs and other BHCs with Assets over \$50 Billion as of June 30, 2003, Panel Data Estimation for the Period 1998-2002, with Year and BHC Fixed Effects

\begin{tabular}{|c|c|c|c|c|}
\hline Dependent variable & $\begin{array}{l}\text { Number of } \\
\text { Mergers }\end{array}$ & $\begin{array}{l}\text { Number of } \\
\text { Mergers }\end{array}$ & $\begin{array}{c}\text { Ratio of Assets } \\
\text { Acquired to } \\
\text { Total Assets }\end{array}$ & $\begin{array}{c}\text { Ratio of Assets } \\
\text { Acquired to } \\
\text { Total Assets }\end{array}$ \\
\hline excregcap & $\begin{array}{r}-.087 \\
(-.23)\end{array}$ & & $\begin{array}{l}-.022 \\
(-.24)\end{array}$ & \\
\hline excregcap $(1-2)$ & & $\begin{array}{c}.31 \\
(.80)\end{array}$ & & $\begin{array}{c}.10 \\
(1.03)\end{array}$ \\
\hline $\operatorname{excregcap}(>2)$ & & $\begin{array}{l}.13 \\
(.16)\end{array}$ & & $\begin{array}{l}-.025 \\
(-.13)\end{array}$ \\
\hline expense ratio & $\begin{array}{r}-.039 \\
(-1.03)\end{array}$ & $\begin{array}{l}-.036 \\
(-.94)\end{array}$ & $\begin{array}{c}-.018 \\
(-1.67)\end{array}$ & $\begin{array}{r}-.017 \\
(-1.53)\end{array}$ \\
\hline hpchange & $\begin{array}{l}.082 \\
(.58)\end{array}$ & $\begin{array}{l}.10 \\
(.71)\end{array}$ & $\begin{array}{l}.017 \\
(.37)\end{array}$ & $\begin{array}{l}.021 \\
(.46)\end{array}$ \\
\hline Year 1999 & $\begin{array}{l}-.44 \\
(-.98)\end{array}$ & $\begin{array}{l}-.33 \\
(-.69)\end{array}$ & $\begin{array}{c}-.35 * * \\
(-2.68)\end{array}$ & $\begin{array}{l}-.35 * * \\
(-2.70)\end{array}$ \\
\hline Year 2000 & $\begin{array}{c}-.87 \\
(-1.52)\end{array}$ & $\begin{array}{c}-.75 \\
(-1.31)\end{array}$ & $\begin{array}{l}-.48 * * \\
(-2.68)\end{array}$ & $\begin{array}{l}-.47 * * \\
(-2.79)\end{array}$ \\
\hline Year 2001 & $\begin{array}{c}-1.05+ \\
(-1.77)\end{array}$ & $\begin{array}{r}-.92+ \\
(-1.64)\end{array}$ & $\begin{array}{r}-.33+ \\
(-1.93)\end{array}$ & $\begin{array}{r}-.33+ \\
(-1.95)\end{array}$ \\
\hline Year 2002 & $\begin{array}{l}-1.52 * \\
(-2.57)\end{array}$ & $\begin{array}{l}-1.45^{*} \\
(-2.46)\end{array}$ & $\begin{array}{l}-.47^{* *} \\
(-2.75)\end{array}$ & $\begin{array}{l}-.47 * * \\
(-2.79)\end{array}$ \\
\hline Estimation procedure: & $\begin{array}{l}\text { Neg. Binomial } \\
\text { regression }\end{array}$ & $\begin{array}{l}\text { Neg. Binomial } \\
\text { regression }\end{array}$ & $\begin{array}{l}\text { Tobit } \\
\text { regression }\end{array}$ & $\begin{array}{l}\text { Tobit } \\
\text { regression }\end{array}$ \\
\hline no. of obs. & 75 & 75 & 75 & 75 \\
\hline no. of BHCs & 15 & 15 & 15 & 15 \\
\hline
\end{tabular}

Note: t-statistics in parentheses. .+, ${ }^{*}$, and $* *$ indicate significance at the 10,5 , and 1 percent levels, respectively. Four of nineteen BHCs are omitted from the analysis because they made no acquisitions during the time period. 
Table 4

The Relationship Between Merger Activity and "Excess Regulatory Capital" for Mandatory A-IRB BHCs and other BHCs with Assets over \$15 Billion as of June 30, 2003, Panel Data Estimation for the Period 1998-2002, with Year and BHC Fixed Effects

\begin{tabular}{|c|c|c|c|c|}
\hline Dependent variable & $\begin{array}{l}\text { Number of } \\
\text { Mergers }\end{array}$ & Number of Mergers & $\begin{array}{l}\text { Ratio of Assets } \\
\text { Acquired to } \\
\text { Total Assets }\end{array}$ & $\begin{array}{l}\text { Ratio of Assets } \\
\text { Acquired to } \\
\text { Total Assets }\end{array}$ \\
\hline excregcap & $\begin{array}{l}.19 \\
(.99)\end{array}$ & & $\begin{array}{c}.049 \\
(1.09)\end{array}$ & \\
\hline excregcap $(1-2)$ & & $\begin{array}{c}.31 \\
(1.17)\end{array}$ & & $\begin{array}{c}.069 \\
(.95)\end{array}$ \\
\hline excregcap $(>2)$ & & $\begin{array}{c}.42 \\
(1.03)\end{array}$ & & $\begin{array}{l}.095 \\
(.89)\end{array}$ \\
\hline expense ratio & $\begin{array}{r}-.026 \\
(-1.13)\end{array}$ & $\begin{array}{r}-.031 \\
(-1.32)\end{array}$ & $\begin{array}{l}-.016^{* *} \\
(-2.68)\end{array}$ & $\begin{array}{l}-.017^{* * *} \\
(-2.75)\end{array}$ \\
\hline hpchange & $\begin{array}{r}.089 \\
(1.04)\end{array}$ & $\begin{array}{c}.10 \\
(1.20)\end{array}$ & $\begin{array}{l}-.034 \\
(-1.26)\end{array}$ & $\begin{array}{l}-.033 \\
(-1.23)\end{array}$ \\
\hline Year 1999 & $\begin{array}{r}-.65^{*} \\
(-2.46)\end{array}$ & $\begin{array}{r}-.62 * \\
(-2.28)\end{array}$ & $\begin{array}{c}-.18 * \\
(-2.31)\end{array}$ & $\begin{array}{c}-.18^{*} \\
(-2.30)\end{array}$ \\
\hline Year 2000 & $\begin{array}{l}-1.06^{* *} \\
(-2.95)\end{array}$ & $\begin{array}{l}-1.12 * * \\
(-3.26)\end{array}$ & $\begin{array}{c}-.16 \\
(-1.52)\end{array}$ & $\begin{array}{l}-.17 \\
(-1.61)\end{array}$ \\
\hline Year 2001 & $\begin{array}{l}-1.20 * * \\
(-3.06)\end{array}$ & $\begin{array}{l}-1.25 * * \\
(-3.36)\end{array}$ & $\begin{array}{c}-.15 \\
(-1.37)\end{array}$ & $\begin{array}{c}-.17 \\
(-1.52)\end{array}$ \\
\hline Year 2002 & $\begin{array}{l}-1.63 * * \\
(-4.46)\end{array}$ & $\begin{array}{l}-1.66^{* *} \\
(-4.69)\end{array}$ & $\begin{array}{l}-.31 * * \\
(-3.10)\end{array}$ & $\begin{array}{c}-.32 * * \\
(-3.22)\end{array}$ \\
\hline Estimation procedure: & $\begin{array}{l}\text { Neg. Binomial } \\
\text { regression }\end{array}$ & $\begin{array}{l}\text { Neg. Binomial } \\
\text { regression }\end{array}$ & $\begin{array}{l}\text { Tobit } \\
\text { regression }\end{array}$ & $\begin{array}{l}\text { Tobit } \\
\text { regression }\end{array}$ \\
\hline no. of obs. & 165 & 165 & 165 & 165 \\
\hline no. of BHCs & 33 & 33 & 33 & 33 \\
\hline
\end{tabular}

Note: t-statistics in parentheses. .+, *, and ** indicate significance at the 10, 5, and 1 percent levels, respectively. Five of thirty-eight BHCs are omitted from the analysis because they made no acquisitions during the time period. 
Table 5

The Relationship Between Merger Activity and "Excess Regulatory Capital" for Mandatory A-IRB BHCs and BHCs with more than \$50 Billion in Assets as of June 30, 2003, Panel Data Estimation for the Period 1993-2002, with Year and BHC Fixed Effects

\begin{tabular}{|c|c|c|c|c|}
\hline Dependent variable & $\begin{array}{l}\text { Number of } \\
\text { Mergers }\end{array}$ & $\begin{array}{l}\text { Number of } \\
\text { Mergers }\end{array}$ & $\begin{array}{c}\text { Ratio of Assets } \\
\text { Acquired to } \\
\text { Total Assets } \\
\end{array}$ & $\begin{array}{c}\text { Ratio of Assets } \\
\text { Acquired to } \\
\text { Total Assets }\end{array}$ \\
\hline excregcap & $\begin{array}{r}.035 \\
(0.24)\end{array}$ & & $\begin{array}{l}.021 \\
(.54)\end{array}$ & \\
\hline excregcap $(1-2)$ & & $\begin{array}{c}.31 \\
(1.46)\end{array}$ & & $\begin{array}{r}.095 \\
(1.57)\end{array}$ \\
\hline excregcap $(>2)$ & & $\begin{array}{c}.48 \\
(1.55)\end{array}$ & & $\begin{array}{c}.11 \\
(1.34)\end{array}$ \\
\hline expense ratio & $\begin{array}{l}-.044^{*} \\
(-2.21)\end{array}$ & $\begin{array}{l}-.050^{*} \\
(-2.51)\end{array}$ & $\begin{array}{c}-.013^{*} \\
(-2.47)\end{array}$ & $\begin{array}{l}-.013^{*} \\
(-2.51)\end{array}$ \\
\hline hpchange & $\begin{array}{c}-.067 \\
(-1.15)\end{array}$ & $\begin{array}{c}-.050 \\
(-1.40)\end{array}$ & $\begin{array}{l}-.0044 \\
(-.33)\end{array}$ & $\begin{array}{l}-.0042 \\
(-.32)\end{array}$ \\
\hline \multicolumn{5}{|l|}{ (Year fixed effects not shown) } \\
\hline Estimation procedure: & $\begin{array}{l}\text { Neg. Binomial } \\
\text { Regression }\end{array}$ & $\begin{array}{l}\text { Neg. Binomial } \\
\text { Regression }\end{array}$ & $\begin{array}{l}\text { Tobit } \\
\text { Regression }\end{array}$ & $\begin{array}{l}\text { Tobit } \\
\text { Regression }\end{array}$ \\
\hline No. of obs. & 170 & 170 & 170 & 170 \\
\hline No. of BHCs & 17 & 17 & 17 & 17 \\
\hline
\end{tabular}

Note: t-statistics in parentheses. .,$+ *$, and ** indicate significance at the 10,5 , and 1 percent levels, respectively. Two of nineteen BHCs are omitted from the analysis because they made no acquisitions during the time period. 
Table 6

The Relationship Between Merger Activity and "Excess Regulatory Capital" for Mandatory A-IRB BHCs and BHCs with more than $\$ 15$ Billion in Assets as of June 30, 2003, Panel Data Estimation for the Period 1993-2002, with Year and BHC Fixed Effects

\begin{tabular}{|c|c|c|c|c|}
\hline Dependent variable & $\begin{array}{l}\text { Number of } \\
\text { Mergers }\end{array}$ & $\begin{array}{l}\text { Number of } \\
\text { Mergers }\end{array}$ & $\begin{array}{c}\text { Ratio of Assets } \\
\text { Acquired to } \\
\text { Total Assets }\end{array}$ & $\begin{array}{c}\text { Ratio of Assets } \\
\text { Acquired to } \\
\text { Total Assets }\end{array}$ \\
\hline excregcap & $\begin{array}{r}.14+ \\
(1.91)\end{array}$ & & $\begin{array}{r}.033 \\
(1.43)\end{array}$ & \\
\hline excregcap (1-2) & & $\begin{array}{r}.42 * \\
(2.32)\end{array}$ & & $\begin{array}{c}.065 \\
(1.38)\end{array}$ \\
\hline excregcap $(>2)$ & & $\begin{array}{r}.57 * \\
(2.49)\end{array}$ & & $\begin{array}{c}.082 \\
(1.39)\end{array}$ \\
\hline expense ratio & $\begin{array}{r}-.018 \\
(-1.52)\end{array}$ & $\begin{array}{c}-.021+ \\
(-1.79)\end{array}$ & $\begin{array}{l}-.0077^{*} \\
(-2.51)\end{array}$ & $\begin{array}{l}-.0080 * \\
(-2.62)\end{array}$ \\
\hline hpchange & $\begin{array}{l}-.031 \\
(-.98)\end{array}$ & $\begin{array}{l}-.031 \\
(-.98)\end{array}$ & $\begin{array}{c}-.01 \\
(-1.30)\end{array}$ & $\begin{array}{c}-.01 \\
(-1.25)\end{array}$ \\
\hline (Year fixed effects not shown) & & & & \\
\hline Estimation procedure: & $\begin{array}{l}\text { Neg. Binomial } \\
\text { Regression }\end{array}$ & $\begin{array}{l}\text { Neg. Binomial } \\
\text { Regression }\end{array}$ & $\begin{array}{l}\text { Tobit } \\
\text { Regression }\end{array}$ & $\begin{array}{l}\text { Tobit } \\
\text { Regression }\end{array}$ \\
\hline No. of obs. & 360 & 360 & 360 & 360 \\
\hline No. of BHCs & 36 & 36 & 36 & 36 \\
\hline
\end{tabular}

Note: t-statistics in parentheses. .,$+{ }^{*}$, and $* *$ indicate significance at the 10,5 , and 1 percent levels, respectively. Two of thirty-eight BHCs are omitted from the analysis because they made no acquisitions during the time period. 
Table 7

Yearly Averages of the Number of Mergers Before and After "Prompt Corrective Action" and the Change from Before to After "Prompt Corrective Action" for Mandatory A-IRB BHCs and other BHCs with greater than \$50 Billion in Assets as of June 30, 2003

\begin{tabular}{l|c|c|c}
\hline & $(1)$ & $(2)$ & $(3)$ \\
\cline { 2 - 4 } & $\begin{array}{c}\text { Average number } \\
\text { of mergers per } \\
\text { year, 1987-1989 }\end{array}$ & $\begin{array}{c}\text { Average number } \\
\text { of mergers per } \\
\text { year, 1991-1992 }\end{array}$ & $\begin{array}{c}\text { Change between } \\
\text { the two periods }\end{array}$ \\
\hline $\begin{array}{l}\text { (a) BHCs not constrained before but constrained } \\
\text { after "prompt corrective action" (9 obs) }\end{array}$ & 1.63 & .61 & -1.02 \\
(b) BHCs not constrained in either period (7 obs) & 1.33 & 1.50 & -17 \\
(c) Difference between the groups, (a) - (b) & .30 & -.89 & -1.19 \\
(d) t-statistic for the difference in (c) & .54 & -1.35 & -1.46 \\
\hline
\end{tabular}

${ }_{1}$ assumes unequal variance. Differences may reflect rounding error. 
Table 8

Yearly Averages of the Number of Mergers Before and After "Prompt Corrective Action" and the Change from Before to After "Prompt Corrective Action" for Mandatory A-IRB BHCs and other BHCs with greater than \$15 Billion in Assets as of June 30, 2003

\begin{tabular}{l|c|c|c}
\hline & $(1)$ & $(2)$ & $(3)$ \\
\cline { 2 - 4 } & $\begin{array}{c}\text { Average number } \\
\text { of mergers per } \\
\text { year, 1987-1989 }\end{array}$ & $\begin{array}{c}\text { Average number } \\
\text { of mergers per } \\
\text { year, 1991-1992 }\end{array}$ & $\begin{array}{c}\text { Change between } \\
\text { the two periods }\end{array}$ \\
\hline $\begin{array}{l}\text { (a) BHCs not constrained before but constrained } \\
\text { after "prompt corrective action" (11 obs) }\end{array}$ & 1.48 & .54 & -.94 \\
(b) BHCs not constrained in either period (17 obs) & 1.08 & .76 & -.31 \\
(c) Difference between the groups, (a) - (b) & .41 & -.22 & -.63 \\
(d) t-statistic for the difference in (c) & .91 & -.64 & -1.18 \\
\hline
\end{tabular}

${ }_{1}^{1}$ assumes unequal variance. Differences may reflect rounding error. 